\title{
HUBUNGAN DISMENORE PRIMER DENGAN PRESTASI BELAJAR MAHASISWI PROGRAM STUDI ILMU KOMUNIKASI FISIP UNUD
}

\author{
Made Edi Pramana Putra ${ }^{1}$, I Gusti Ayu Pramitaresthi², Ni Putu Emy Darma Yanti ${ }^{3}$ \\ ${ }^{1}$ Mahasiswa Program Studi Sarjana Keperawatan dan Profesi Ners Fakultas Kedokteran Universitas Udayana \\ ${ }^{2,3}$ Dosen Program Studi Sarjana Keperawatan dan Profesi Ners Fakultas Kedokteran Universitas Udayana \\ Alamat Korespondensi: edipramana090797@gmail.com
}

\begin{abstract}
Abstrak
Sebagian besar remaja wanita mengalami dismenore primer. Efek dari dismenore primer memengaruhi aktivitas dan salah satunya adalah belajar. Aktivitas belajar yang terganggu akan memengaruhi prestasi belajar wanita. Tujuan penelitian ini untuk mengetahui hubungan dismenore primer dengan prestasi belajar mahasiswi Program Studi Ilmu Komunikasi Fakultas Ilmu Sosial dan Ilmu Politik Universitas Udayana (FISIP Unud). Desain penelitian menggunakan analitik korelatif melalui pendekatan cross sectional dengan pengambilan data retrospektif. Responden adalah mahasiswi Program Studi Ilmu Komunikasi angkatan 2016-2018 FISIP Unud yang mengalami dismenore primer berjumlah 65 mahasiswi. Teknik pengambilan sampel menggunakan teknik proportionate stratified random sampling. Analisis data yang digunakan adalah univariat dalam bentuk tabel frekuensi dan bivariat dengan uji Korelasi Gamma $(\alpha=0,05)$. Berdasarkan analisis data diperoleh hasil yaitu dari 65 mahasiswi yang mengalami dismenore primer paling banyak mengalami dismenore sedang sebanyak 37 mahasiswi $(56,9 \%)$ dan paling banyak mendapatkan predikat prestasi belajar dengan pujian sebanyak 57 mahasiswi $(87,7 \%)$. Hasil uji Korelasi Gamma menunjukkan bahwa p < 0,05 $(\mathrm{p}=0,001)$ dan nilai korelasi $(r)=-$ 1,000. Berdasarkan hal tersebut dapat disimpulkan terdapat hubungan dismenore primer dengan prestasi belajar mahasiswi Program Studi Ilmu Komunikasi FISIP Unud, dengan arah hubungan negatif yaitu semakin tinggi dismenore primer maka semakin rendah prestasi belajar dan sebaliknya dengan kekuatan korelasi secara statistik sangat kuat. Diharapkan mahasisiwi mampu memilih upaya yang tepat untuk meningkatkan prestasi belajar.
\end{abstract}

Kata kunci: Dismenore Primer, Mahasiswi, Prestasi Belajar

\begin{abstract}
Most young women experience primary dysmenorrhea. The primary dysmenorrhea affect activity especially learning. Disrupted learning activities will affect women's learning achievement. The purpose of this study was to determine the relationship between primary dysmenorrhea and the learning achievement of Communication Study Program students FISIP Unud. The design of the research is a correlative analytics through a cross sectional approach with retrospective data collection. Respondents were 65 female students of 2016-2018 who experienced primary dysmenorrhea. The sampling used the proportionate stratified random sampling. Analysis used are frequency tables for univariate and Gamma Correlation test for bivariates $(\alpha=0,05)$. Data obtained results from 65 female students who experienced primary dysmenorrhea had the most moderate dysmenorrhea as many as 37 female students $(56.9 \%)$ and at most received the title of learning achievement with praise of 57 students $(87.7 \%)$. The Gamma Correlation test results show that $p<0.05(p=0.001)$ and the correlation value $(r)$ $=-1,000$. Based on this, it can be concluded that there was a relationship between primary dysmenorrhea and the learning achievement of Communication Study Program students FISIP Unud, with a negative relationship direction that is the higher the primary dysmenorrhea, the lower the learning achievement and vice versa with the power of correlation was statistically very strong. It is expected that students will be able to choose the right effort to improve learning achievement.
\end{abstract}

Keywords: Learning Achievement, Primary Dysmenorrhea, Students 


\section{PENDAHULUAN}

Remaja wanita memiliki pengalaman menstruasi yang unik. Sebagian remaja mengalami menstruasi dengan nyaman, namun tidak sedikit dari mereka yang mengalami menstruasi tidak nyaman sehingga menimbulkan keluhan yang disebut dengan dismenore primer. Dismenore primer umumnya terjadi pada masa remaja, sekitar dua sampai tiga tahun setelah menarche (Shaleh, 2017). Dismenore primer merupakan nyeri menstruasi yang terjadi selama siklus ovulatorik tanpa adanya gangguan fisik. Penyebab dismenore primer adalah adanya hormon yang jumlahnya berlebih pada darah menstruasi sehingga merangsang hiperaktivitas dari uterus yaitu prostaglandin $\mathrm{F}_{2 \alpha}$ (Bernardi et al., 2017).

Dismenore primer adalah dismenore yang paling sering dikeluhkan remaja wanita di Indonesia. Berdasarkan penelitian Santi dan Pribadi (2018), diperoleh bahwa 97 dari 192 wanita usia 18-25 tahun $(50,50 \%)$ yang berkunjung ke klinik Universitas Islam Negeri Sunan Ampel, Surabaya mengalami keluhan menstruasi seperti dismenore primer sebanyak 66 orang $(68,05 \%)$. Penelitian Sutawinata \& Primayanti (2017) juga menyatakan bahwa dari 96 mahasiswi Pendidikan Dokter Fakultas Kedokteran Universitas Udayana, Denpasar Bali sebesar 69 mahasiswi $(71,9 \%)$ mengalami dismenore primer.

Dismenore primer yang dirasakan dapat mengganggu aktivitas wanita. Efek dari dismenore primer selain menimbulkan rasa tidak nyaman berupa nyeri, juga menimbulkan berbagai gejala lain seperti mual, muntah, sakit kepala, pusing, letih, diare, emosi yang labil selama menstruasi, bahkan pingsan (Reeder \& Koniak, 2011). Wanita merasakan efek dismenore primer hingga mampu menghambat aktivitas biasanya (Gebeyehu, et al. 2017). Salah satu aktivitas wanita adalah belajar.

Optimalnya proses belajar dipengaruhi oleh kesehatan fisik. Pelajar yang mengalami dismenore primer merasakan nyeri sebagai perasaan tidak mengenakkan yang memungkinkan terganggunya aktivitas belajar (Putri dkk., 2017). Aktivitas belajar yang terganggu akan memengaruhi prestasi belajar. Prestasi belajar merupakan gambaran domain kognitif, afektif dan psikomotor siswa dalam lingkungan pendidikan yang dinyatakan dalam indeks terukur (Kpolovie et al., 2014). Salah satu alat ukur prestasi belajar mahasiswa adalah Indeks Prestasi Kumulatif (IPK).

Ilmu sosial didefinisikan sebagai disiplin akademis yang mempelajari aspek yang berkaitan dengan manusia dan lingkungan sosialnya (Hastuti, 2015). Seseorang yang mempelajari ilmu sosial pada umumnya jarang mendapat pengetahuan mengenai kesehatan (Bulahari dkk., 2015). Pengetahuan kesehatan terkait dismenore primer yang kurang tentu akan memengaruhi penanganannya dan penanganan yang tidak tepat akan memengaruhi aktivitas wanita termasuk aktivitas belajar, aktivitas belajar menjadi tidak sempurna dan prestasi belajar pun akan terpengaruh. Salah satu fakultas di bidang sosial di Bali adalah Fakultas Ilmu Sosial dan Ilmu Politik Universitas Udayana (FISIP Unud) yang memiliki enam program studi, dan Program Studi Ilmu Komunikasi yang memiliki jumlah mahasiswi paling banyak.

Berdasarkan studi pendahuluan yang dilakukan, pada tanggal 10 Oktober 2018 dengan metode wawancara terhadap 10 mahasiswi Ilmu Komunikasi FISIP Unud dari angkatan 2016-2018, diperoleh hasil bahwa empat orang mengatakan tidak mengetahui dismenore dan belum pernah mendapatkan informasi terkait dismenore. Delapan dari sepuluh mahasiswi mengeluh mengalami dismenore primer, dan enam dari delapan mahasiswi yang mengalami dismenore primer merasakan efek dismenore primer hingga memengaruhi aktivitas sehari-hari termasuk aktivitas belajar dan pernah mengalami penurunan IPK, bahkan dua mahasiswi rutin 
mengalami dismenore primer setiap bulannya hingga membuat mahasiswi sampai tidak mengikuti proses perkuliahan.

Berdasarkan hal tersebut maka peneliti ingin melakukan penelitian lebih lanjut dengan judul "Hubungan Dismenore Primer dengan Prestasi Belajar Mahasiswi Program Studi Ilmu Komunikasi Fakultas Ilmu Sosial dan Ilmu Politik Universitas Udayana".

\section{METODE PENELITIAN}

Penelitian menggunakan desain analitik korelatif melalui pendekatan cross sectional dengan pengambilan data retrospektif. Penelitian ini telah lulus uji Kelaikan Etik oleh Komisi Etik Penelitian Fakultas Kedokteran Universitas Udayana/Rumah Sakit Umum Pusat Sanglah Denpasar nomor 664/UN14.2.2.VII.14/LP/2019. Populasi penelitian adalah mahasiswi Program Studi Ilmu Komunikasi angkatan 2016-2018 FISIP Unud yang mengalami dismenore primer sebanyak 77 mahasiswi. Jumlah sampel adalah 65 mahasiswi yang memenuhi kriteria inklusi. Pengambilan sampel dengan menggunakan teknik Proportionate Stratified Random
Sampling. Data dismenore primer dikumpulkan melalui pengukuran skala nyeri dismenore Numerical Rating Scale (NRS). Data prestasi belajar dalam bentuk nilai IPK dikumpulkan melalui Kasubag Akademik dan Kemahasiswaan FISIP Unud.

Peneliti melakukan kontrak waktu dengan responden, kemudian menjelaskan penelitian serta penandatanganan lembar persetujuan (informed consent). Selanjutnya responden diminta untuk mengisi lembar pengukuran skala nyeri (NRS). Angka yang dipilih kemudian dikelompokkan menjadi dismenore ringan (1-3), dismenore sedang (4-6), dan dismenore berat (7-10). Data prestasi belajar (IPK) diperoleh dari Kasubag Akademik dan Kemahasiswaan FISIP Unud. Nilai dikelompokkan menjadi memuaskan (2,00-2,75), sangat memuaskan (2,76-3,50), dan dengan pujian $(3,51-4,00)$. Terakhir melakukan analisis data menggunakan uji Korelasi Gamma dengan tingkat kepercayaan 95\% $(\mathrm{p} \leq 0,05)$ melalui perhitungan software computer.

\section{HASIL PENELITIAN}

Tabel 1. Distribusi Frekuensi Derajat Dismenore Primer dan Predikat Prestasi Belajar Mahasiswi Program Studi Ilmu Komunikasi Fakultas Ilmu Sosial dan Ilmu Politik Universitas Udayana

\begin{tabular}{cccccc}
\hline $\begin{array}{c}\text { Derajat } \\
\text { Dismenore } \\
\text { Primer }\end{array}$ & $\begin{array}{c}\text { Frekuensi } \\
(\mathbf{n})\end{array}$ & $\begin{array}{c}\text { Persentase } \\
(\boldsymbol{\%})\end{array}$ & $\begin{array}{c}\text { Predikat Prestasi } \\
\text { Belajar }\end{array}$ & $\begin{array}{c}\text { Frekuensi } \\
(\mathbf{n})\end{array}$ & $\begin{array}{c}\text { Persentase } \\
(\boldsymbol{\%})\end{array}$ \\
\hline Ringan & 21 & 32,3 & Sangat Memuaskan & 8 & 12,3 \\
\hline Sedang & 37 & 56,9 & 10,8 & & $\begin{array}{c}\text { Dengan } \\
\text { Pujian }\end{array}$ \\
\hline Berat & 7 & & & 57 & 87,7 \\
\hline JUMLAH & 65 & 100,0 & & 65 & 100,0 \\
\hline
\end{tabular}

Berdasarkan tabel 1 dari 65 mahasiswi yang mengalami dismenore primer paling banyak mengalami dismenore sedang sebanyak 37 mahasiswi $(56,9 \%)$ serta paling banyak mendapatkan predikat prestasi belajar dengan pujian sebanyak 57 mahasiswi $(87,7 \%)$. 
Tabel 2. Hubungan Dismenore Primer dengan Prestasi Belajar Mahasiswi Program Studi Ilmu Komunikasi Fakultas Ilmu Sosial dan Ilmu Politik Universitas Udayana

\begin{tabular}{|c|c|c|c|c|c|}
\hline \multirow{3}{*}{$\begin{array}{l}\text { Dismenore } \\
\text { Primer }\end{array}$} & \multicolumn{3}{|c|}{ Prestasi Belajar } & \multirow{3}{*}{$\begin{array}{c}\text { Koefisien } \\
\text { Korelasi (r) }\end{array}$} & \multirow{3}{*}{$\begin{array}{c}\text { Hasil Uji Korelasi } \\
\text { Gamma }\end{array}$} \\
\hline & $\begin{array}{c}\text { Sangat } \\
\text { Memuaskan }\end{array}$ & $\begin{array}{c}\text { Dengan } \\
\text { Pujian }\end{array}$ & Total & & \\
\hline & $\begin{array}{c}\mathbf{n} \\
(\%)\end{array}$ & $\begin{array}{c}\mathbf{n} \\
(\%)\end{array}$ & $\begin{array}{c}\mathbf{n} \\
(\%)\end{array}$ & & \\
\hline Ringan & $\begin{array}{c}0 \\
(0,0)\end{array}$ & $\begin{array}{c}21 \\
(32,3)\end{array}$ & $\begin{array}{c}21 \\
(32,3)\end{array}$ & $-1,000$ & $p=0,001$ \\
\hline Sedang & $\begin{array}{c}1 \\
(1,5)\end{array}$ & $\begin{array}{c}36 \\
(55,4)\end{array}$ & $\begin{array}{c}37 \\
(56,9)\end{array}$ & & \\
\hline Berat & $\begin{array}{c}7 \\
(10,8) \\
\end{array}$ & $\begin{array}{c}0 \\
(0,0) \\
\end{array}$ & $\begin{array}{c}7 \\
(10,8) \\
\end{array}$ & & \\
\hline JUMLAH & $\begin{array}{c}8 \\
(12,3)\end{array}$ & $\begin{array}{c}57 \\
(87,7)\end{array}$ & $\begin{array}{c}65 \\
(100,0)\end{array}$ & & \\
\hline
\end{tabular}

*Tingkat kepercayaan 95\%, $\alpha=0,05$, nilai $\mathrm{p}<0,05$

Berdasarkan tabel 2 dari 65 mahasiswi yang mengalami dismenore primer hampir keseluruhan mahasiswi dengan dismenore ringan dan sedang memeroleh predikat prestasi belajar dengan pujian yaitu 57 mahasiswi $(87,7 \%)$, sedangkan pada mahasiswi yang mengalami dismenore berat keseluruhan mendapatkan predikat prestasi belajar sangat memuaskan yaitu tujuh mahasiswi $(10,8 \%)$

Hasil uji Korelasi Gamma diperoleh nilai $p=0,001(\alpha<0,05)$ artinya $\mathrm{H}_{0}$ ditolak sehingga dapat dikatakan ada hubungan secara signifikan antara dismenore primer dengan prestasi belajar mahasiswi Program Studi Ilmu Komunikasi Fakultas Ilmu Sosial dan Ilmu Politik Universitas Udayana. Nilai korelasi $(\mathrm{r})=-1,000$ yang berarti semakin tinggi dismenore primer maka semakin rendah prestasi belajar atau sebaliknya semakin rendah dismenore primer maka semakin tinggi prestasi belajar dengan kekuatan korelasi secara statistik sangat kuat.

\section{PEMBAHASAN}

Mayoritas mahasiswi mengalami dismenore sedang sebanyak 37 mahasiswi $(56,9 \%)$. Hal ini dikarenakan salah satu faktor yang memengaruhi dismenore primer yaitu faktor umur saat ini. Semakin bertambahnya usia maka semakin sering ia mengalami menstruasi yang menyebabkan leher rahim semakin lebar, leher rahim yang semakin lebar mengakibatkan sekresi hormon prostaglandin akan semakin berkurang (Aditiara, 2018; Angelia dkk., 2017; Aprilyadi dkk., 2018). Hal ini juga sejalan dengan Silvanus dkk. (2017), yang menyatakan bahwa toleransi terhadap nyeri akan meningkat seiring dengan bertambahnya usia. Dismenore yang dirasakan juga dapat berbeda-beda atau tingkatan sesuai dengan yang dirasakan mahasiswi. Oleh sebab itu nyeri bersifat individual dan unik antara setiap orang (Fillingim, 2017).

Predikat prestasi belajar mahasiswi sebagian besar dengan pujian yaitu 57 mahasiswi (87,7\%). Secara umum kesehatan seseorang akan memengaruhi kegiatan belajar, proses belajar seseorang menjadi terganggu jika kesehatan orang terganggu. Hal ini sejalan dengan Aisyah (2015), yang menyatakan bahwa kondisi kesehatan sangat memengaruhi proses belajar sebab badan yang lemah dan lelah mengakibatkan perhatian tidak mungkin konsentrasi, badan kurang vitamin menyebabkan kegiatan belajar tidak bergairah, dan badan yang sakit tidak mungkin melakukan kegiatan belajar dengan sempurna.

Akan tetapi hasil penelitian menunjukkan bahwa sebagian besar mahasiswi yang mengalami dismenore primer mendapatkan predikat prestasi belajar dengan pujian. Hasil ini sejalan dengan penelitian Sumartini dkk. (2018), yang menyatakan sebagian besar 
mahasiswi yang mengalami dismenore mendapatkan prestasi belajar yang lebih tinggi dibandingkan dengan yang tidak mengalami dismenore. Hal ini dikarenakan prestasi belajar dipengaruhi oleh berbagai faktor. Hal tersebut juga sejalan dengan Slameto (2010), yang menyatakan prestasi belajar dipengaruhi oleh dua faktor yaitu faktor internal dan faktor eksternal. Faktor internal adalah faktor yang ada dalam individu yang sedang belajar seperti, faktor jasmaniah yang meliputi kesehatan dan cacat tubuh, faktor psikologis yang meliputi intelegensi, perhatian, minat, bakat, motivasi, kematangan, kesiapan, dan faktor kelelahan. Sedangkan faktor eksternal yang mungkin memengaruhi prestasi belajar diantaranya keadaan keluarga, keadaan sekolah, dan keadaan masyarakat.

Hasil penelitian yang dilakukan pada 65 mahasiswi yang mengalami dismenore primer hampir keseluruhan mahasiswi dengan dismenore ringan dan sedang memeroleh predikat prestasi belajar dengan pujian yaitu 57 mahasiswi $(87,7 \%)$, sedangkan pada mahasiswi yang mengalami dismenore berat keseluruhan mendapatkan predikat prestasi belajar sangat memuaskan yaitu tujuh mahasiswi $(10,8 \%)$. Hasil uji korelasi mendapatkan ada hubungan secara signifikan antara dismenore primer dengan prestasi belajar mahasiswi Program Studi Ilmu Komunikasi Fakultas Ilmu Sosial dan Ilmu Politik Universitas Udayana. Hasil analisis nilai korelasi diperoleh semakin tinggi dismenore primer maka semakin rendah prestasi belajar atau sebaliknya.

Wanita yang mengalami dismenore primer merasakan rasa tidak nyaman berupa rasa sakit atau nyeri pada tubuh yang memungkinkan terganggunya aktivitas belajar. Dismenore primer selain menimbulkan rasa tidak nyaman berupa nyeri, juga menimbulkan berbagai gejala lain seperti mual, muntah, sakit kepala, pusing letih, diare, emosi yang labil selama menstruasi bahkan pingsan (Reeder \& Koniak, 2011). Efek dismenore primer yang dirasakan dapat mencegah wanita untuk beraktivitas secara normal. Dismenore primer memiliki dampak negatif terhadap aktivitas belajar mahasiswi dan aktivitas belajar yang terganggu akan memengaruhi prestasi belajar (Hailemeskel et al, 2016; Septiyaningsih, 2017). Dismenore primer yang dirasakan dapat memengaruhi aktivitas belajar mahasiswi dengan tidak konsentrasi dalam menerima pelajaran di kelas maupun saat mengerjakan ujian bahkan nyeri yang semakin meningkat dapat meningkatkan ketidakhadiran mahasiswi dalam proses perkuliahan sehingga dapat memengaruhi prestasi belajar. Hal ini didukung oleh penelitian Fajarini dkk. (2018), yang menyatakan bahwa terdapat hubungan antara dismenore primer dengan prestasi belajar yaitu prestasi belajar rendah tiga kali lebih sering ditemukan pada remaja dengan dismenore primer. Penelitian lain juga menyatakan bahwa dampak dari dismenore primer selain menyebabkan rendahnya konsentrasi di kelas juga memberikan dampak pada penurunan kinerja akademik, peningkatan absen di kelas, rendahnya hubungan personal, penurunan nafsu makan, merasa depresi, mengubah pola tidur, dan membatasi latihan fisik (Ameade et al., 2018; Derseh, et al., 2017; Gebeyehu, et al., 2017; Yesuf et al., 2018).

\section{KESIMPULAN DAN SARAN}

Dismenore primer memengaruhi aktivitas remaja wanita, mahasiswi merasakan berbagai efek dari dismenore primer hingga memengaruhi aktivitas belajar. Mahasiswi menjadi tidak konsentrasi dalam menerima pelajaran di kelas maupun saat mengerjakan ujian bahkan nyeri yang semakin meningkat dapat meningkatkan ketidakhadiran mahasiswi dalam mengikuti proses perkuliahan. Aktivitas belajar yang terganggu tentu akan memengaruhi prestasi belajar mahasiswi. Berdasarkan hasil uji Korelasi Gamma diperoleh 
adanya hubungan secara signifikan antara dismenore primer dengan prestasi belajar mahasiswi Program Studi Ilmu Komunikasi Fakultas Ilmu Sosial dan Ilmu Politik Universitas Udayana. Korelasi memiliki arah negatif yang berarti semakin tinggi dismenore primer maka semakin rendah prestasi belajar atau sebaliknya semakin rendah dismenore primer maka semakin tinggi prestasi belajar dengan kekuatan korelasi secara statistik sangat kuat.

Bagi mahasiswi hasil penelitian ini dapat memberikan gambaran hubungan dismenore primer dengan prestasi belajar yang dimiliki sehingga bisa mengantisipasi atau memilih upaya yang tepat untuk meningkatkan prestasi belajar dan mempertimbangkan faktor-faktor lain yang memengaruhi prestasi belajar. Bagi Institusi dapat dijadikan bahan masukan perencanaan program kesehatan reproduksi dan mengembangkan program intervensi kesehatan di kampus untuk mengatasi dismenore primer supaya tidak mengganggu prestasi belajar mahasiswi. Bagi peneliti selanjutnya agar meneliti faktor-faktor lain yang mungkin memengaruhi dismenore primer dan prestasi belajar.

\section{DAFTAR PUSTAKA}

Aditiara, B. E. (2018). Hubungan antara usia menarche dengan dysmenorrhea primer. Universitas Muhammadiyah Surakarta. Diunduh dari http://eprints.ums.ac.id/ (Diakses pada 03 Mei 2019).

Aisyah, S. (2015). Perkembangan peserta didik \& bimbingan belajar. Edisi 1 cetakan 1. Yogyakarta: Deepublish. Diunduh dari https://books.google.co.id/ (Diakses pada 10 Februari 2019).

Ameade, E. P. K., Amalba, A., \& Mohammed, B. S. (2018). Prevalence of dysmenorrhea among university students in Northern Ghana; Its impact and management strategies. BMC Women's Health. Diunduh dari https://www.researchgate.net/ (Diakses pada 20 Oktober 2018).

Angelia, L. M., Sitorus, R. J., \& Etrawati, F. (2017). Model prediksi kejadian dismenore primer pada siswi SMA Negeri di Palembang. Jurnal Ilmu Kesehatan Masyarakat. Diunduh dari http://jikm.unsri.ac.id/ (Diakses pada 20 Oktober 2018).

Aprilyadi, N., Feri, H. J., \& Ridawati, I. D. (2018). Efektifitas hypnotherapi terhadap penurunan nyeri dismenorea pada siswi SMA. Jurnal Perawat Indonesia. Vol. 2. No. 1. Diunduh dari https://journal.ppnijateng.org/ (Diakses pada 22 Juni 2019).

Bernardi, M., Lazzeri, L., Perelli, F., Reis, F. M., \& Petraglia, F. (2017). Dysmenorrhea and related disorders. Diunduh dari https://www.ncbi.nlm.nih.gov/ (Diakses pada 29 Mei 2019).

Bulahari, S. N., Korah, H. B., \& Lontaan, A. (2015). Faktor-faktor yang memengaruhi pengetahuan remaja tentang kesehatan reproduksi. Jurnal Ilmiah Bidan. Vol. 3, No. 2. Diunduh dari https://www.neliti.com/id/ (Diakses pada 20 Oktober 2018).

Derseh, B. T., Afessa, N., Temesgen, M., Semayat, Y. W., Kassaye, M., Sieru, S., Gizachew, S. \& Ketsela, K. (2017). Prevalence of dysmenorrhea and its effect on school performance: A cross sectional study. Journal of Women's Health Care Vol.6. Diunduh dari https://www.omicsonline.org/ (Diakses pada 19 Oktober 2018).

Fajarini, Y. I., Nurdianti, D. S., \& Padmawati, R. S. (2018). Prestasi belajar pada remaja yang mengalami dismenore primer. Jurnal Kesehatan Reproduksi. Vol. 5. No. 1. Diunduh dari 
https://jurnal.ugm.ac.id/ (Diakses pada 08 Februari 2019).

Fillingim, R. B. (2017). Individual differences in pain: understanding the mosaic that makes pain personal. Diunduh dari https://www.ncbi.nlm.nih.gov/ (Diakses pada 29 Mei 2019).

Gebeyehu, M. B., Mekuria, A. B., Tefera, Y. G., Andarge, D. A., Debay, Y. B., Bejiga, B. S., \& Gebresillassie, B. M. (2017). Prevalence, impact, and management practice of dysmenorrhea among University of Gondar students, Northwestern Ethiopia: A cross-sectional study. International Journal of Reproductive Medicine. Diunduh dari https://www.ncbi.nlm.nih.gov/ (Diakses pada 20 Oktober 2018).

Hailemeskel, S., Demissie, A., \& Assefa, N. (2016). Primary dysmenorrhea magnitude, associated risk factors, and its effect on academic performance: Evidence from female university students in Ethiopia. International Journal of Women's Health. Diunduh dari https://www.ncbi.nlm.nih.gov/ (Diakses pada 22 Juni 2019).

Hastuti, W. (2015). Perbedaan ilmu alam dan ilmu sosial. Kompasiana. Diunduh dari https://www.kompasiana.com/ (Diakses pada 18 September 2018).

Kpolovie, P. J., Joe, A. I., \& Okoto, T. (2014). Academic achievement prediction: role of interest in learning and attitude towards school. International Journal of Humanities Social Sciences and Education. Vol. 1, Issue 11. Diunduh dari https://www.arcjournals.org/ (Diakses pada 20 Oktober 2018).

Putri, S. A., Yunus, M., \& Fanani, E. (2017). Hubungan antara nyeri haid (dismenore) terhadap aktivitas belajar pada siswi kelas XI SMA Negeri 52 Jakarta. Universitas
Negeri Malang. Diunduh dari http://journal.um.ac.id/ (Diakses pada 16 September 2018).

Reeder, M., \& Koniak, G. (2011). Keperawatan maternitas kesehatan wanita, bayi dan keluarga. Eds. 18, Vol. 1. Jakarta: Penerbit Buku Kedokteran EGC.

Santi, D. R. \& Pribadi, E. T. (2018). Kondisi gangguan menstruasi pada pasien yang berkunjung di Klinik Pratama UIN Sunan Ampel. Journal of Health Science and Prevention. Vol 2(1). Diunduh dari jurnalfpk.uinsby.ac.id/ (Diakses pada 07 Oktober 2018).

Septiyaningsih, S. (2017). Pengaruh aktivitas belajar dan kemandirian belajar terhadap prestasi belajar mahasiswa. Jurnal Pendidikan Dan Ekonomi. Vol. 6. No. 3. Diunduh dari http://journal.student.uny.ac.id/ (Diakses pada 08 Februari 2019).

Shaleh, A. Q. (2017). Buah hati: Antara perhiasan dan ujian keimanan. Buku Elektronik. Yogyakarta : Diandra Kreatif. Diunduh dari https://books.google.co.id/ (Diakses pada 18 Oktober 2018).

Silvanus, Mudayatiningsih, S., \& Rahayu, W. (2017). Hubungan regulasi emosi dengan intensitas nyeri dismenore primer pada remaja putri di SMAN 7 Malang. Nursing News. Vol. 2, No. 3. Diunduh dari https://publikasi.unitri.ac.id/ (Diakses pada 03 Mei 2019).

Slameto. (2010). Belajar dan faktor-faktor yang memengaruhinya. Edisi Revisi. Jakarta : PT. Rineka Cipta.

Sumartini, Hasnah, Risnah, \& Syisnawati. (2018). Hubungan dysmenorrhea dengan prestasi belajar mahasiswi jurusan keperawatan. Journal of Islamic Nursing. Vol. 3, No. 1. Diunduh dari https://journal.uinalauddin.ac.id/ (Diakses pada 03 Mei 2019).

Sutawinata, A. A. \& Primayanti, D. A. I. D. (2017). Hubungan kebiasaan 
olahraga aerobik terhadap dismenore primer pada mahasiswi 18-24 tahun Fakultas Kedokteran Universitas Udayana. E-Jurnal Medika. Vol. 6, No. 12. Diunduh dari https://ojs.unud.ac.id/ (Diakses pada 22 Juni 2019).

Yesuf, T. A., Eshete, N. A., \& Sisay, N. A. (2018). Dysmenorrhea among university health science students, Northern Ethiopia: Impact and associated factors. International Journal of Reproductive Medicine. Diunduh dari https://www.hindawi.com/ (Diakses pada 20 Oktober 2018). 